\title{
STANDARDIZATION OF RECIPE AND DRYING METHOD FOR CANDY MAKING OF AONLA (EMBLICA OFFICINALIS GAERTN) CV. GUJARAT AONLA-1
}

\author{
P. N. KORE, VIRENDRA SINGH, BHARODIA C. R, MAHETA H. Y,
} P. A. MAHERIYA \& LOKESH YADAV

Department of Horticulture, Junagadh Agricultural University, Junagadh, Gujarat, India

ABSTRACT
\[ \text { An investigation was conducted in the post graduate Laboratory, Department of Horticulture, Junagadh } \]
Agricultural University, Junagadh during the year 2011-12, to study the "standardization of recipe and drying method
for candy making of aonla (Emblica officinalis Gaertn.) cv. Gujarat Aonla-1". There were nine treatment combinations
of different recipe and drying methods. The experiment was laid out in a Factorial Completely Randomized Design, with
three repetitions. The treatment $R_{3}(80 \%$ sugar solution) showed the maximum $T S S$ and total sugars, in aonla candy
whereas, the maximum titrable acidity and ascorbic acid were observed in the $R_{1}(60 \%$ sugar solution). The chemical
characteristics like TSS, titrable acidity, ascorbic acid and total sugars were obtained maximum in the $D_{1}$ treatment (Sun
drying), in the candies of aonla at all the storage periods. The treatment combination $R_{3} D_{1}(80 \%$ sugar solution and sun
drying) was recorded the highest total sugars, whereas the terrible acidity in aonla candies were recorded in the $R_{1} D_{1}$.
KEYWORDS: Aonla Candy, Recipe and Drying Methods

Received: Jul 08, 2017; Accepted: Jul 26, 2017; Published: Aug 01, 2017; Paper Id.: IJASRAUG201778

\section{INTRODUCTION}

Aonla or Indian goose berry (Emblica officinalis Gaertn, syn. Phyllanthus emblica Linn.) is one of the most important indigenous fruit of Indian origin. Aonla is known since ancient time for medicinal and nutritional value. It is a rich source of ascorbic acid, pectin and polyphenols which impart acidic and astringent taste to fruit. Its composition makes good medicinal value as antisorbutic, diuretic, laxative and antibiotic. The fruit also posses pronounced expectorant, antiviral, cardiotonic and hypologlycaemic activity. It is widely used in the Unani and Aurvedic system of Medicine (Kalra, 1988). Aonla becomes ready for harvesting from mid November to first week of January. The produce remains in the market for a very short period. Since it is a perishable commodity, it needs quick disposal. Huge harvest of produce during peak harvesting season creates glut and the growers are compelled to sell their produce at distress prices. The post harvest losses in aonla vary from 30 to 40 per cent, due to its perishable nature and glut during harvesting time, which reduce the market value of the fruit. Owing to restricted availability and high perishability of aonla fruits, value addition through processing into variety of products would be the only effective tool for economic utilization, to boost the production of aonla fruits.

Moreover aonla fruit is acrid and of bitter taste, hence utilized after processing. So many varieties have been released in our country viz. Krishna, Kanchan, Banarasi, Gujarat Aonla -1 and NA-7.

The fresh fruits are not consumed due to their high astringency; however it is known for its great medicinal as well as therapeutic properties and also has good processing quality. Hence, variety of products like 
aonla murabba, preserve, candy, squash, dried flecks, tablets, Jam, jelly, pickle, toffees, powder, Juice, pulp, much was, chocolate, syrup, pan masala, amchoor, churan, chavanprash, mouth freshner, laddoo, chutney, supari, cold drinks, capsules and aonla pak etc. can be successfully prepared from aonla fruit. Thus, keeping in view the potentialities of the processed aonla product the experiment was entitled, "Standardization of recipe and drying method for candy making of aonla (Emblica officinalis Gaertn.) cv. Gujarat Anola-2 fruit".

\section{MATERIALS AND METHODS}

An investigation was carried out in the post graduate Laboratory, Department of Horticulture, Junagadh Agricultural University, Junagadh during 2011-12. Completely Randomized Design with Factorial concept was followed in the experiment with two factor viz. Factor A: Different recipe, Factor B: drying method and their combinations.

The aonla fruits were dipped in water for discarding light and infested fruits. These fruits were then cleaned under running tap water to remove impurities and dust from the surface of fruits. The fruits were cut into pieces with uniform size, then blanched in boiling water at $98 \pm 2{ }^{\circ} \mathrm{C}$ for 2-3 $\mathrm{min}$ as per the method suggested by Kadam et al, 1991. Then Sugar syrup was made with different recipe and dried with different drying methods then the packaging of candy of each treatment under study was done in polypropylene (pp) pouches of $50 \mu$ thickness of $100 \mathrm{~g}$ packets and was stored during February-April, 2012 at room temperature $\left(18.2-38.2{ }^{\circ} \mathrm{C}\right.$ and 17.2-79.3 \% RH) for a period of 3 months \& observations were recorded at an interval of 30 days.

\section{RESULTS AND DISCUSSIONS}

The experimental results revealed that the candy making significantly influenced due to different recipe and drying method of aonla.

Table 1: Effect of Recipe and Methods on Quality Parameters of Aonla Candy at Drying $90^{\text {th }}$ Days

\begin{tabular}{|c|c|c|c|c|c|}
\hline Treatment & Treatment Details & TSS ( ${ }^{0}$ Brix) & Acidity (\%) & $\begin{array}{c}\text { Ascorbic Acid } \\
(\mathbf{m g} / 100 \mathrm{~g})\end{array}$ & Total Sugars (\%) \\
\hline \multicolumn{6}{|l|}{ A. Recipe } \\
\hline $\mathrm{R}_{1}$ & $60 \%$ sugar solution & 61.44 & 1.07 & 331.82 & 60.54 \\
\hline $\mathrm{R}_{2}$ & $70 \%$ sugar solution & 71.50 & 0.97 & 314.40 & 69.35 \\
\hline $\mathrm{R}_{3}$ & $80 \%$ sugar solution & 81.67 & 0.93 & 231.00 & 76.05 \\
\hline \multicolumn{2}{|l|}{ S. Em. \pm} & 0.21 & 0.00 & 0.89 & 0.24 \\
\hline C.D. at 5\% & & 0.62 & 0.02 & 2.50 & 0.71 \\
\hline \multicolumn{6}{|c|}{ B. Drying Method } \\
\hline $\mathrm{D}_{1}$ & Sun drying & 71.89 & 1.02 & 299.02 & 71.55 \\
\hline $\mathrm{D}_{2}$ & Oven drying & 71.89 & 0.99 & 293.83 & 68.08 \\
\hline $\mathrm{D}_{3}$ & Tray drying & 70.83 & 0.95 & 284.38 & 66.35 \\
\hline \multicolumn{2}{|l|}{ S.Em. \pm} & 0.21 & 0.00 & 0.89 & 0.24 \\
\hline \multicolumn{2}{|l|}{ C.D. at $5 \%$} & 0.62 & 0.02 & 2.50 & 0.71 \\
\hline \multirow{2}{*}{\multicolumn{2}{|c|}{$\begin{array}{l}\text { C.V. \% } \\
\text { Interaction }\end{array}$}} & 0.88 & 1.23 & 0.91 & 1.05 \\
\hline & & NS & SIG. & NS & SIG. \\
\hline
\end{tabular}

Table 2: Interaction Effects of Recipe and Drying Methods on Quality Parameters of Aonla Candy at $90^{\text {th }}$ days

\begin{tabular}{|l|c|c|c|}
\hline Treatment $(\mathbf{R} \times \mathbf{D})$ & Acidity (\%) & $\begin{array}{c}\text { Ascorbic Acid } \\
(\mathbf{m g} / \mathbf{1 0 0} \mathbf{g})\end{array}$ & $\begin{array}{c}\text { Total } \\
\text { Sugars }(\%)\end{array}$ \\
\hline $\mathrm{R}_{1} \mathrm{D}_{1}$ & 1.10 & 335.77 & 63.70 \\
\hline \multicolumn{4}{|c|}{ Table 2: Contd., } \\
\hline $\mathrm{R}_{1} \mathrm{D}_{2}$ & 1.05 & 332.37 & 59.29 \\
\hline
\end{tabular}




\begin{tabular}{|l|c|c|c|}
\hline $\mathrm{R}_{1} \mathrm{D}_{3}$ & 1.05 & 327.33 & 58.63 \\
\hline $\mathrm{R}_{2} \mathrm{D}_{1}$ & 1.00 & 323.79 & 71.27 \\
\hline $\mathrm{R}_{2} \mathrm{D}_{2}$ & 0.98 & 314.62 & 69.26 \\
\hline $\mathrm{R}_{2} \mathrm{D}_{3}$ & 0.95 & 304.80 & 67.53 \\
\hline $\mathrm{R}_{3} \mathrm{D}_{1}$ & 0.97 & 237.50 & 79.69 \\
\hline $\mathrm{R}_{3} \mathrm{D}_{2}$ & 0.95 & 234.50 & 75.69 \\
\hline $\mathrm{R}_{3} \mathrm{D}_{3}$ & 0.86 & 221.00 & 72.88 \\
\hline S.Em.土 & 0.01 & 1.54 & 0.42 \\
\hline C.D. at 5\% & 0.03 & $\mathrm{NS}$ & 1.27 \\
\hline C.V. \% & 1.23 & 0.91 & 1.05 \\
\hline
\end{tabular}

\section{Different Recipe and Drying Method}

Among the different recipes, significantly maximum TSS (81.67 Brix) and total sugars (76.05\%) at 90th day was found in $\mathrm{R}_{3}$ (80\% sugar solution), whereas, significantly lowest TSS and total sugar was found in $\mathrm{R}_{1}(60 \%$ sugar solution). While, significantly maximum acidity (1.07\%) and ascorbic acid $(331.82 \mathrm{mg} / 100 \mathrm{~g})$ at 90 th day was found in $\mathrm{R}_{1}(60 \%$ sugar solution), whereas, significantly lowest acidity and ascorbic acid was found in $\mathrm{R}_{3}$ (80\% sugar solution). In case of drying treatment, at 90th day significantly maximum TSS (71.890Brix) was found in $\mathrm{D}_{1}$ (Sun drying) and $\mathrm{D}_{2}$ (Oven drying). While, maximum acidity, ascorbic acid and total sugar $(1.02 \%, 299.02 \mathrm{mg} / 100 \mathrm{~g}$ and $71.55 \%)$ was found in $\mathrm{D}_{1}$ (Sun drying) respectively, whereas, lowest TSS, acidity, ascorbic acid and total sugar was found in $\mathrm{D}_{3}$ (Try drying) in aonla candy (Table 1).

The decrease in ascorbic acid in candies during storage might be due to oxidation or irreversible conversion of Lascorbic acid into dehydro ascorbic acid oxidase (ascorbimase). The decrease in ascorbic acid might also be due to its oxidation to dihydroxy-ascorbic acid, during the storage period and high temperature during tray drying. And in decrease in ascorbic acid during storage period was also reported by Gupta et al. (1980) in ber candy, Kumar (1998) in papaya candy, Antala (2010) in guava slices.

\section{Interaction Effect of Recipe and Drying Methods}

It is evident from data that, the interaction effect of recipe treatments and drying methods on titrable acidity content at 90th day of storage was found maximum in $R_{1} D_{1}(1.10 \%)$ which was found at par with $R_{1} D_{2}$ and $R_{1} D_{3}$, whereas lower acidity $(0.86 \%)$ was found in $\mathrm{R}_{3} \mathrm{D}_{3}$. At 90 th day of storage ascorbic acid content of aonla candy was found nonsignificant. Maximum total sugars was found in $\mathrm{R}_{3} \mathrm{D}_{1}(79.69 \%)$, at 90 th day during storage while, significantly minimum total sugars was found in $\mathrm{R}_{1} \mathrm{D}_{3}$ (Table 2).

\section{CONCLUSIONS}

Results have clearly indicated that, the treatment $\mathrm{R}_{3} \mathrm{D}_{1}(80 \%$ sugar solution and sun drying) was best for the chemical characteristics of aonla and citrus peel candies, because the sun drying regulates the process of osmosis and concentration of sugar in the candies. Different drying methods reduce the growth and development of microbes in the product, during storage.

Hence, it is the best method for the value addition of the fruits like aonla for earning more income.

\section{REFERENCES}

1. Antala. D. K. (2010). Packaging and storage studies on fresh guava fruits and Osmotic-air dehydrated powder of guava (Psidium guajava L). Unpublished Ph. D. Thesis, Junagadh Agriculture University, Junagadh, Gujarat, (India). 
2. Gupta, O. P, Kainsa, R. L. and Chauvan, K.S. (1980). Post-harvest studies on ber fruits: Preparation of candy. Haryana Agric. Univ. J. Res. 10 (2): 163-165.

3. Kadam, S. S, Chavan, U.D. and Dhotre, V. A. (1991). Processing of ber-I. Preparation of ready to serve beverage and candy. Beverage and Food World. 18(3): 13-14.

4. Kalra, C. L. (1988). The chemistry and technology of Amla (Phyllanthus emblica): A resume. Indian Fd. Pack, 42 (4): 67.

5. Kumar, Sanjeev and Singh, I.S. (1998). Studies on processing of papaya (Carica papaya L.) fruits. Prog. Hort. 30(3/4): 139147. 